\title{
Dolomite Lime's Reaction Applied on the Surface of a Sandy Soil of the Northwest Paraná, Brazil
}

\author{
Anderson R. Meda; Marcos A. Pavan*; Marcelo E. Cassiolato and Mário Miyazawa \\ Instituto Agronômico do Paraná (IAPAR); Caixa Postal 481; CEP 86001-970; Londrina - PR - Brasil
}

\begin{abstract}
Low Ca and Mg are serious limitations to crop production in sandy soils of the northwest Paraná, Brazil. Thus soil samples of an Oxisol collected in this region were packed into $30 \mathrm{~cm}$ long columns. Dolomite lime (2.0, 0.84, 0.30, and $<0.30 \mathrm{~mm}$ screen) was added on soil surface, then leached with deionized water. Thereafter, the columns were dismantled and the soil cut into $5 \mathrm{~cm}$ segments for chemical analysis. Dolomite lime increased $\mathrm{pHCaCl}, \mathrm{KCl}_{2}$ exchangeable $\mathrm{Ca}$ and $\mathrm{Mg}$ and residual $\mathrm{CO}_{3}$ mostly in the top surface layers. Surface dolomite lime had no effect on $\mathrm{pH}, \mathrm{Ca}, \mathrm{Mg}$, and $\mathrm{CO}_{3}$ in the leachate, independent on the lime particle size. These results indicated that surface dolomite lime application had no effect on subsoil composition and mostly of the calcium and magnesium carbonates are still unreacted on the soil surface.
\end{abstract}

Key words: Liming, $\mathrm{Ca}$ and $\mathrm{Mg}$ leaching, subsoil acidity

\section{INTRODUCTION}

Among the major soil limitations to crop production in northwest Paraná State, Brazil are: extremely deficient levels of $\mathrm{Ca}, \mathrm{Mg}$, and $\mathrm{K}$, low cation exchange capacity (CEC) and organic matter contents, and very sandy texture. Fidalski \& Auler (1997) and Fidalski et al. (1999) observed that $\mathrm{Ca}$ and $\mathrm{Mg}$ were the highest nutritional deficiencies in citrus orchards in this region. They also demonstrated that leaf $\mathrm{Ca}$ and $\mathrm{Mg}$ were positively related with citrus yields. They concluded that dolomite lime is essential for an economic citrus production in this soil.

In long-term pasture and in established perennial crops where deep soil cultivation is not possible, lime may be spread on soil surface and allowed time to leach. Even when cultivation is possible in citrus orchard, lime incorporation is unlikely with conventional machinery and leaching of the ions from the lime is relied upon for amelioration of acidity deeper in the soil. There are some evidences that surface applied lime in this soil has little effect on both surface and subsurface chemical properties (Rêgo, 1997; Fidalski, 1999). These authors reported that soil samples taken after twelve months of dolomite lime application on soil surface showed no effects on $\mathrm{pH}$ and $\mathrm{KCl}-$ exchangeable $\mathrm{Ca}, \mathrm{Mg}$, and $\mathrm{Al}$. Their hypotheses are that lime was either leached bellow the root zone or was still unreacted with the soil acidity. To test these hypotheses, laboratory experiments were conducted with PVC columns with soil samples collected in this region to identify the main chemical reactions involved in the surface applied dolomite lime.

\footnotetext{
${ }^{*}$ Author for correspondence
} 


\section{MATERIAL AND METHODS}

Soil samples were collected from a cultivated site on the Instituto Agronômico do Paraná (IAPAR) experimental station at Paranavaí, Brazil $\left(23^{\circ} 05^{\prime} \mathrm{S}\right.$, $52^{\circ} 26^{\prime} \mathrm{W}, 480 \mathrm{~m}$ above sea level). This soil was selected based on following characteristics: sandy texture, low basic cations contents, and their potential use for production of citrus and pasture. The soil had an original $\mathrm{pH} \mathrm{CaCl}_{2}$ value of 5.0; exchangeable $\mathrm{Ca}, \mathrm{Mg}$ and $\mathrm{K}$ contents of $12.8,6.6$, and $3.0 \mathrm{mmolc} \mathrm{dm}-3$, respectively; total acidity $(\mathrm{H}$ $+\mathrm{Al}$ ) of 29.4 mmolc dm-3, organic carbon content of $10.31 \mathrm{~g} \mathrm{~kg}-1$ and clay, silt, and sand contents of 11,1 , and $88 \%$, respectively.

Columns (length $30 \mathrm{~cm}$; diameter $4 \mathrm{~cm}$ ) of rigid polyvinyl chloride (PVC) were used to conduct the experiment. Soil samples were transferred to PVC column and compacted to a homogeneous bulk density (mean $1.4 \mathrm{~g} \mathrm{~cm}-3$ ). Then, the columns were brought to field capacity with distilled water. Approximately $1 \mathrm{~kg}$ of agricultural dolomite limestone $(27.3 \% \mathrm{CaO}, 20.7 \% \mathrm{MgO}$, and $100 \%$ neutralizer power) containing both coarse and fine materials was passed through 2.0, 0.84, 0.30, and $<0.30 \mathrm{~mm}$ screen. A mechanical shaker was used to separate the lime particle sizes.

Lime was added on the soil surface at a rate of $3.96 \mathrm{~g}$ per column in order to neutralize two times the total acidity $(\mathrm{H}+\mathrm{Al})$ contents. The irrigation program was $330 \mathrm{ml}$ of water per column, equivalent to three porous volume, added at a rate of $2.2 \mathrm{ml} \mathrm{min}-1$.

At each porous volume, the drainage water was collected and analyzed for $\mathrm{pH}, \mathrm{Ca}, \mathrm{Mg}$ and $\mathrm{CO} 3$ contents. Soil samples were collected at 0-5, 5-10, $10-15,15-20$ and $20-25 \mathrm{~cm}$ depth, air dried, ground to pass $2 \mathrm{~mm}$ sieve and analyzed for $\mathrm{pH}$ $\mathrm{CaCl} 2, \mathrm{KCl}$-exchangeable $\mathrm{Ca}$ and $\mathrm{Mg}$, and total $\mathrm{CO} 3$. $\mathrm{Ca}$ and $\mathrm{Mg}$ were determined by $\mathrm{ICP}$ (Inductively Coupled Plasma) and total $\mathrm{CO} 3$ content by conductivimetry using flow injection analysis coupled with pervaporation (Kawazaki et al., 2000, Grassi, et al., 2002). All treatments had three replicates in a completely randomized block design.

\section{RESULTS AND DISCUSSION}

Figures 1, 2, 3 and 4 show soil $\mathrm{pH}, \mathrm{KCl}-$ exchangeable $\mathrm{Ca}$ and $\mathrm{Mg}$ and total $\mathrm{CO} 3$ content at different depths as a result of surface application of dolomitic lime. For simplicity, data included only the effects of control, the coarsest $(2.0 \mathrm{~mm})$ and the finest limestone $(<0.3 \mathrm{~mm})$.

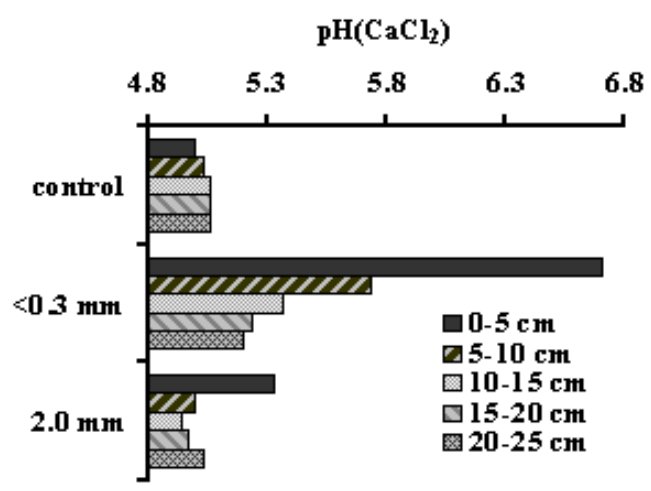

Figure 1 - Effect of surface applied dolomite lime on soil $\mathrm{pH}$.

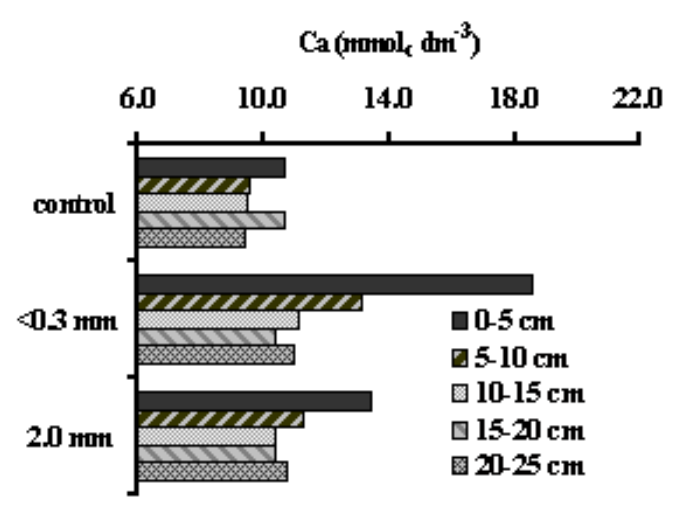

Figure 2 - Effect of surface applied dolomite lime on exchangeable soil $\mathrm{Ca}$ content.

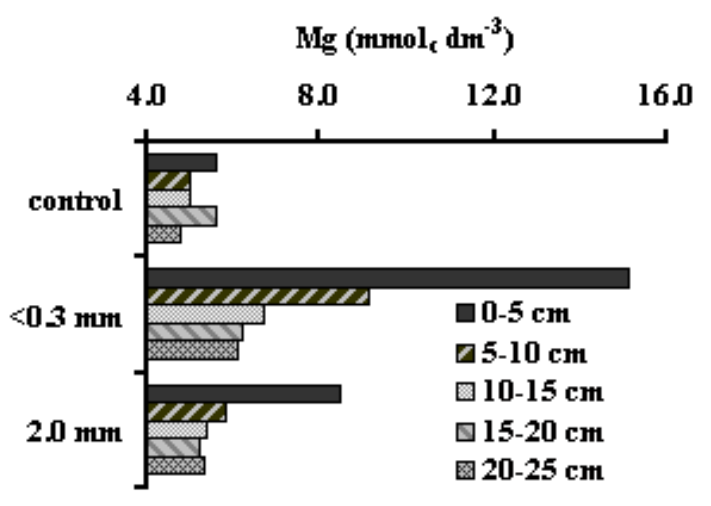

Figure 3 - Effect of surface applied dolomite lime on exchangeable soil $\mathrm{Mg}$ content. 


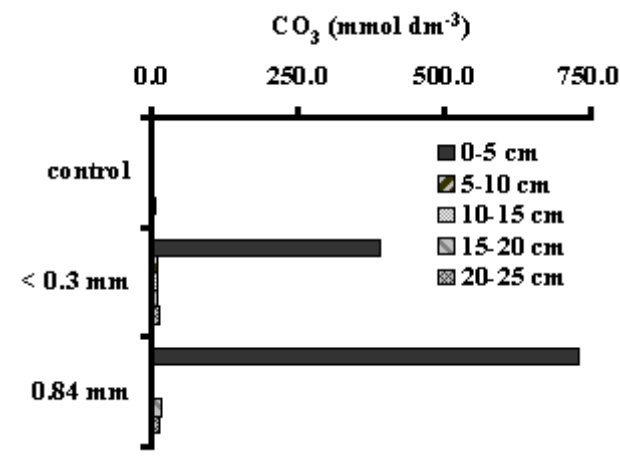

Figure 4 - Effect of surface applied dolomite lime on total soil $\mathrm{CO}_{3}$ content.

Dolomitic lime increased $\mathrm{pH}$, exchangeable $\mathrm{Ca}$, $\mathrm{Mg}$, and $\mathrm{CO} 3$ mostly in the top surface layers. The finest the lime the highest the increase in $\mathrm{pH}, \mathrm{Ca}$ and $\mathrm{Mg}$, corroborating data presented by Verlengia \& Gargantini (1972). The lime particle size had not clear effect on the mobility of $\mathrm{Ca}$ and $\mathrm{Mg}$ with depth. The low $\mathrm{Ca}$ and $\mathrm{Mg}$ distribution patterns can be explained by the electrical neutrality principles which state that $\mathrm{Ca}$ and $\mathrm{Mg}$ can not move down in the soil profile unless accompanied by equivalent anions.

Figures 5, 6, 7 and 8 show the effect of surface applied dolomite lime on drainage water composition. $\mathrm{Ca}, \mathrm{Mg}, \mathrm{CO} 3$ and $\mathrm{pH}$ in the leachates were consistent and complementary to their distributions in the soil profile.

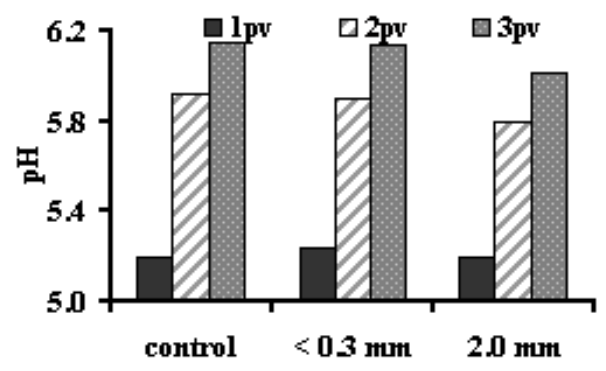

Figure 5 - Effect of surface applied dolomite lime on drainage water $\mathrm{pH}$.

With increasing $\mathrm{pV}$, there was an increase in $\mathrm{pH}$ and a decrease in $\mathrm{Ca}, \mathrm{Mg}$ and $\mathrm{CO}_{3}$ concentrations as a result of dilution. Surface applied dolomite had little effect on drainage water $\mathrm{pH}, \mathrm{Ca}, \mathrm{Mg}$ and $\mathrm{CO}_{3}$. These results (soil and drainage) indicated little mobility of surface applied lime in this sandy soil and most of calcium and magnesium carbonates were still unreacted on the soil surface.

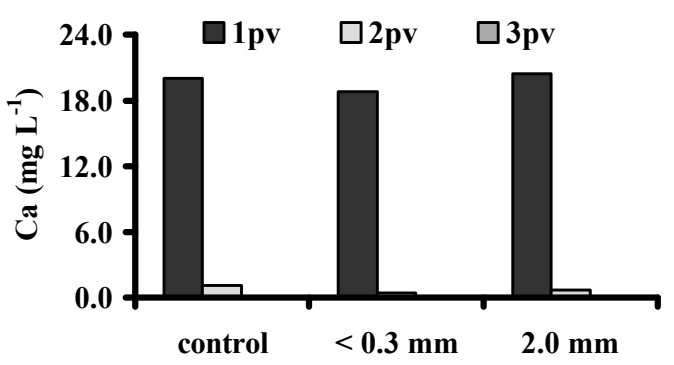

Figure 6 - Effect of surface applied dolomite lime on drainage water $\mathrm{Ca}$.

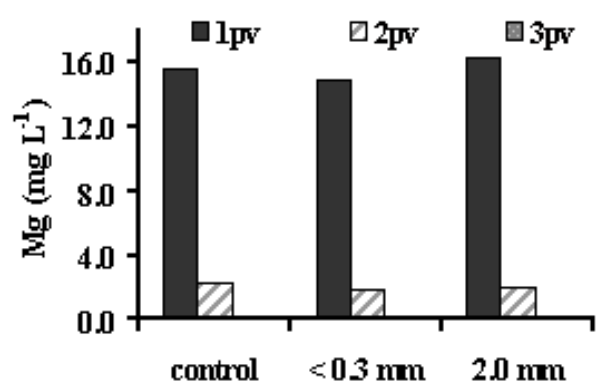

Figure 7 - Effect of surface applied dolomite lime on drainage water $\mathrm{Mg}$.

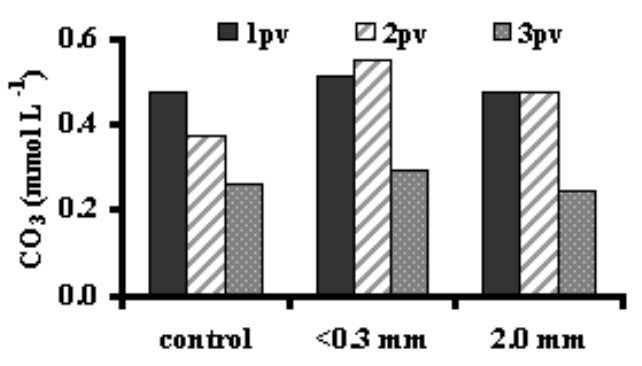

Figure 8 - Effect of surface applied dolomite lime on drainage water $\mathrm{CO}_{3}$.

The low rate of lime movement into the soil profile was probably a result of the low solubility of the $\mathrm{CaMg}\left(\mathrm{CO}_{3}\right)_{2}$, weak soil acidity, and the lack of stable soluble anion as a product of the reaction of dolomite with soil acidity. The electrical neutrality principle dictates that $\mathrm{Ca}$ and $\mathrm{Mg}$ movements must be accompanied by equivalent 
anions. The dolomite lime reaction is illustrated as following:

$$
\begin{aligned}
& \mathrm{CaMg}(\mathrm{CO} 3) 2+4 \mathrm{H}+\rightarrow \mathrm{Ca} 2++\mathrm{Mg} 2++2 \mathrm{CO} 2+ \\
& 2 \mathrm{H} 2 \mathrm{O}
\end{aligned}
$$

This reaction neutralizes $\mathrm{H}+$ and release $\mathrm{Ca} 2+$ and $\mathrm{Mg} 2+$, resulting an increase in soil $\mathrm{pH}$ and $\mathrm{pH}-$ dependent CEC. The $\mathrm{Ca}^{2+}$ and $\mathrm{Mg}^{2+}$ stoichiometrically replace $\mathrm{H}^{+}$on the existing $\mathrm{pH}-$ dependent CEC whose magnitude changes under the influence of the increase alkalinity. As expected, it was found higher exchangeable $\mathrm{Ca}$ than $\mathrm{Mg}$ after dolomite lime reaction in this soil due to higher selectivity of the colloidal negative sites for $\mathrm{Ca}^{2+}$ than for $\mathrm{Mg}^{2+}$ (Loyola \& Pavan, 1989). The above reaction will continue to the right as long as the soil supplies acidity in the form of $\mathrm{H}+$ ions.

The results of this study clearly indicated that surface lime applications in this soil had little effect on the subsoil acidity and most of $\mathrm{Ca}$ and $\mathrm{Mg}$-carbonates are still unreacted on the soil surface. Seldom would lime be applied to a topsoil with the objective of improving the subsoil fertility without any acid inputs. For this soil, without acid inputs, transfer of alkalinity to the subsoil is unexpected.

\section{CONCLUSION}

Agriculturally realistic liming rates are not likely to ameliorating subsurface soil acidity on the Northwest Paraná without acid inputs. The carbonates stay unreacted on the soil surface.

\section{ACKNOWLEDGEMENTS}

The authors wish to thank CNPq for the concession of the scientific initiation scholarship.

\section{RESUMO}

A deficiência de $\mathrm{Ca}$ e $\mathrm{Mg}$ são fatores que podem limitar a produção agrícola nos solos arenosos do Noroeste do Paraná, Brasil. Amostras de um Latossolo Vermelho escuro coletado nesta região foram incubadas em colunas de PVC de $30 \mathrm{~cm}$ de comprimento, aplicando-se calcário dolomítico (peneiras tamanho 2.0, 0.84, 0.30, e $<0.30 \mathrm{~mm}$ ) na superfície, lixiviando-se com água destilada. Após, as colunas de solo foram fragmentadas de 5 em 5 $\mathrm{cm}$. Cada fragmento da coluna constituiu a amostra de solo que foi analisada quimicamente. $\mathrm{O}$ calcário dolomítico aumentou o $\mathrm{pHCaCl}_{2}, \mathrm{Ca}$ e $\mathrm{Mg}$ trocáveis e carbonato residual principalmente na camada superficial $(0-5 \mathrm{~cm})$. A aplicação de calcário dolomítico na superfície apresentou pequeno efeito no $\mathrm{pH}, \mathrm{Ca}, \mathrm{Mg}$ e carbonato na água de drenagem, independente do tamanho da partícula do calcário. Estes resultados indicaram que a aplicação de calcário dolomítico na superfície não alterou a composição química das camadas inferiores do solo e grande parte dos carbonatos de cálcio e magnésio aplicados permaneceram sem reação na superfície do solo.

\section{REFERENCES}

Fidalski, J. (1999), Respostas da mandioca à adubação NPK e calagem em solos arenosos do noroeste do Paraná. Pesq. Agropec. Bras., 34, 1353-1359.

Fidalski, J. and Auler, P. A. M. (1997), Levantamento nutricional de pomares de laranja no noroeste do Paraná. Arq. Biol. Tecnol., 40, 443-451.

Fidalski, J.; Pavan, M. A.; Auler, P. A. M. and Jaocmino, A. P. (1999), Produção de frutos de laranja pêra e teores de nutrientes nas folhas e no solo, em latossolo vermelho-escuro do noroeste do Paraná. R. bras. Ci. Solo, 23, 273-279.

Grassi, V.; Miyazawa, M.; Pavan, M. A. and Kamogawa, M. Y. (2002), Determinação em fluxo do carbonato residual do solo empregando pervaporação. Química Nova, 25, 149-152.

Kawazaki, L. I.; Miyazawa, M.; Pavan, M. A. and Franchini, J. C. (2000), Determinação condutivimétrica de carbonato residual do calcário aplicado no solo por análise em fluxo. Química Nova, 23, 560-562.

Loyola Jr., E. and Pavan, M. A. (1989), Seletividade de troca de cátions em solos ácidos. R. bras. Ci. Solo, 13, 131-138.

Rêgo, I. C. (1997), Calagem e gessagem em um latossolo vermelho escuro cultivado com laranja pêra sobre limoeiro cravo. Piracicaba, CENA-USP. Tese de Doutorado.

Verlengia, F. and Gargantini, H. (1972), Estudo sobre a eficiência de diferentes frações granulométricas de calcário no solo. Bragantia, 31, 119-128.

Received: April 10, 2000; Revised: March 16, 2001; Accepted: November 20, 2001. 